\title{
Perception and Adoption of Nutririch Crops Cultivation Practices among Soliga Farmers
}

\author{
M. S. Uma* and Usha Ravindra \\ AICRP Sunflower, University of Agricultural Sciences, GKVK, Bangalore 560 065, India \\ *Corresponding author
}

\section{A B S T R A C T}

\begin{tabular}{l} 
Ke y w o r d s \\
$\begin{array}{l}\text { Nutririch Crops } \\
\text { Cultivation, } \\
\text { Seed rate }\end{array}$ \\
\hline Article Info \\
$\begin{array}{l}\text { Accepted: } \\
\text { 17 August } 2020 \\
\text { Available Online: } \\
\text { 10 September } 2020\end{array}$ \\
\hline
\end{tabular}

The study was conducted purposively in selected 24 villages of Male mahadeshwara Hills , Chamarajanagara District, Karnataka. The study revealed that cent per cent of soliga farmers perceived Nutririch crop varieties, Soil sample collection and analysis, Seed rate and timely harvesting as more useful followed by application of fertilizers $(80.00 \%)$, Nutrifarms /Kitchen garden establishments (77.33\%). Cent per cent of the soliga farmers completely adopted Nutririch crop varieties, Soil sample collection and analysis, Seed rate, spacing and timely harvesting, followed by application of fertilizers, and Nutrifarms /Kitchen garden establishments $(80.00 \%)$. Many of the soliga farmers have not adopted vermicompost $(45.00 \%)$, intercropping (48.67\%) and Value addition of agricultural produce $(10.00 \%)$. Out of seven characteristics selected for the study, five viz., education, land holding, social participation, risk orientation and decision making ability had significant relationship with perception and adoption. Besides this, innovative proneness had significant relationship with perception. Thus, it is necessary to intensify the extension educational programmes such as trainings, discussion meetings, demonstrations, field visits etc., for needed perceptual changes in nutririch crop cultivators. This will enable the soliga farmers to adopt nutririch crop cultivation practices which in turn will help in the production of quality seeds of nutririch crops and enhance the nutritional status.

\section{Introduction}

The Soliga Tribes, the inhabitants of M.M. Hills are people who live in close association with nature. Many are also concentrated in and around the Male Mahadeshwara hills and Kollegala Taluks of Chamarajanagar District, Karnataka. They grow prominently Ragi, Huruli, Cowpea, Avare and Maize in rainfed situation. As per the recent survey conducted by the NGO, the tribes of MM hills are having nutritional deficiency disorders.
However, there is a high prevalence of iron deficiency anemia among women and children. Generally, at household level, cultural norms and practices and socioeconomic factors determine the extent of nutritional status among farmers.

In this context, the need of the hour is to improve the nutritional status of tribal women and children. In this prospective, the present study was undertaken to popularization of nutritional crops with rural and tribal people 
to improve their nutritional status and to grow nutritional crops as profitable crop through value addition.

It also emphasises on pursuing the farmers to adopt the cultivation of these nutririch crops varieties in their own fields so that these varieties can be made locally available at economical prices both for seed production as well as commercial cultivation.

\section{Materials and Methods}

Twenty four villages of M.M Hills, Kollegala Taluk, Chamarajanagar district were selected.In each village, a list of farmers were prepared separately and 10 farmers from each village were selected randomly, thus making a total sample of 150 and more than 200 acres area covered under this study. The data were collected with the help of structured pretested interview schedule and analysed for drawing conclusions.

\section{Results and Discussion}

The finding obtained from the present study is presented below:

\section{Perception of soliga farmers regarding nutririch crop cultivation practices}

The results presented in Table 1 indicate that cent per cent of soliga farmers perceived Nutririch crop varieties, Soil sample collection and analysis, Seed rate and timely harvesting as more useful followed by Application of fertilizers (80.00\%), Nutrifarms /Kitchen garden establishments $(77.33 \%)$.

The possible reason might be that the soliga farmers felt that these practices were most useful for them. The findings are in conformity with that of Balasubramanian and Perumal (1989), Christinck (2002), Kerr et al., (2007), Kitch et al., (1998) (Table 2).

Table.1 Perception of soliga farmers regarding nutririch crop cultivation practices $(n=150)$

\begin{tabular}{|c|c|c|c|c|c|c|c|}
\hline \multirow{2}{*}{$\begin{array}{l}\text { Sr. } \\
\text { No }\end{array}$} & \multirow[t]{2}{*}{ Nutririch crop cultivation practices } & \multicolumn{2}{|c|}{ More useful } & \multicolumn{2}{|c|}{ Useful } & \multicolumn{2}{|c|}{ Less useful } \\
\hline & & No. & $\%$ & No. & $\%$ & No. & $\%$ \\
\hline 1. & Nutririch crop varieties & 150 & 100 & -- & -- & -- & -- \\
\hline 2. & Soil sample collection and analysis & 150 & 100 & -- & -- & -- & -- \\
\hline 3. & Seed rate & 150 & 100 & -- & -- & -- & -- \\
\hline 4. & Spacing & 98 & 65.33 & 28 & 18.66 & 24 & 16.01 \\
\hline 5. & Application of fertilizers & 120 & 80.00 & 30 & 20.00 & -- & -- \\
\hline 6. & Plant protection measures & 62 & 41.33 & 46 & 30.66 & 42 & 28.00 \\
\hline 7. & Timely Harvesting & 150 & 100 & --- & ---- & -- & --- \\
\hline 8. & Intercropping & 91 & 60.66 & 45 & 30.00 & 14 & 09.34 \\
\hline 9. & Vermicomposting & 60 & 40.00 & 52 & 34.66 & 38 & 25.34 \\
\hline 10. & Value addition of agricultural produce & 62 & 41.33 & 56 & 37.33 & 32 & 21.34 \\
\hline 11. & Nutrifarms /Kitchen garden establishments & 116 & 77.33 & 34 & 22.66 & -- & --- \\
\hline
\end{tabular}


Table. 2 Adoption level of nutririch crop cultivation practices by soliga farmers $(n=150)$

\begin{tabular}{|c|c|c|c|c|c|c|c|}
\hline \multicolumn{8}{|c|}{ Adoption level } \\
\hline \multirow{2}{*}{$\begin{array}{l}\text { Sr. } \\
\text { No }\end{array}$} & \multirow[t]{2}{*}{ Nutririch crop cultivation practices } & \multicolumn{2}{|c|}{ Complete adoption } & \multicolumn{2}{|c|}{ Partial adoption } & \multicolumn{2}{|c|}{ Non-adoption } \\
\hline & & No. & $\%$ & No. & $\%$ & No. & $\%$ \\
\hline 1. & Nutririch crop varieties & 150 & 100.00 & -- & -- & -- & -- \\
\hline 2. & Soil sample collection and analysis & 150 & 100.00 & -- & -- & -- & -- \\
\hline 3. & Seed rate & 150 & 100.00 & -- & -- & -- & -- \\
\hline 4. & Spacing & 150 & 100.00 & -- & -- & -- & -- \\
\hline 5. & Application of fertilizers & 120 & 80.00 & 30 & 20.00 & -- & -- \\
\hline 6. & Plant protection measures & 120 & 80.00 & 30 & 20.00 & -- & -- \\
\hline 7. & Timely Harvesting & 150 & 100.00 & -- & -- & -- & -- \\
\hline 8. & Intercropping & 44 & 29.33 & 33 & 22.00 & 73 & 48.67 \\
\hline 9. & Vermicomposting & 45 & 30.0 & 37 & 25.00 & 68 & 45.00 \\
\hline 10. & Value addition of agricultural produce & 37 & 25.00 & 98 & 65.00 & 15 & 10.00 \\
\hline 11. & $\begin{array}{l}\text { Nutrifarms /Kitchen garden } \\
\text { establishments }\end{array}$ & 150 & 100.00 & -- & -- & -- & -- \\
\hline
\end{tabular}

Table.3 Relationship between characteristics of soliga farmers with their perception and adoption level of nutririch crop cultivation practices

\begin{tabular}{|l|l|c|c|}
\hline Sr. No & Name of the variable & Perception ('r' values) & Adoption('r' values) \\
\hline 1. & Age & 0.209 & 0.212 \\
\hline 2. & Education & $0.346^{* *}$ & $0.431^{* *}$ \\
\hline 3. & Landing & $0.392^{* *}$ & $0.423^{* *}$ \\
\hline $\mathbf{4 .}$ & Social participation & $0.431^{* *}$ & $0.316^{* *}$ \\
\hline $\mathbf{5 .}$ & Innovation proneness & $0.348^{* *}$ & 0.134 \\
\hline 6. & Risk orientation & $0.459^{* *}$ & $0.403^{* *}$ \\
\hline 7. & Decision making ability & $0.362^{* *}$ & $0.395^{* *}$ \\
\hline
\end{tabular}

Adoption level of nutririch crop cultivation practices by soliga farmers

It was observed that cent per cent of the soliga farmers completely adopted Nutririch crop varieties, Soil sample collection and analysis, Seed rate, spacing and timely harvesting, followed by application of fertilizers, and Nutrifarms /Kitchen garden establishments $(80.00 \%)$. Many of the soliga farmers have not adopted vermicompost (45.00\%), intercropping (48.67\%) and value addition of agricultural produce $(10.00 \%)$.
Vermicompost and intercropping practices are important as use of modern practices for higher production in nutririch crop cultivation. However, more than 45 per cent of soliga farmers did not adopt these practices. This might be due to the lack of complete knowledge regarding these practices. The complexity involved during the initial stage of establishment for vermicompost and many of the farmers have their own FYM/compost pits, availability of their own FYM on time may be the possible reason. Most of the soliga farmers preferred solo crop instead of inter cropping during 
cultivation of nutririch crop varieties, it could be easy for them to select the preferred variety based on the yield performance. Ten percent of soliga farmers did not adopt the value addition of agricultural produce, because either they use full farm produce for their family consumption or they confined to the traditional preparations not ready to accept the new formulations. Similar findings were also reported by Usha Ravindra et al., (2020).

\section{Relationship between characteristics of soliga farmers with their perception and adoption level}

It is evident from Table 3 that farmer's age was not related with their perception and adoption of nutririch crop cultivation practices. Education, land holding, social participation, risk orientation and decision making ability exhibited positive and significant relationship with perception and adoption. Besides this, innovative proneness had significant relationship with perception. Similar finding were reported by Balasubbramanian and Perumal (1989) and Madhu Prasad et al., (2010).

In conclusion the study revealed that majority of the soliga farmers perceived that nutririch crop cultivation practices as more useful to enrich their nutritional and economic status. But some practices like, vermicompost and intercropping and value addition of agricultural produce were not adopted by few soliga farmers. Out of seven characteristics six and five characteristics have significant and positive relationship with perception and adoption of nutririch crop cultivation practices respectively. Hence, it is necessary to intensity the extension educational programmes such as trainings, discussion meetings, demonstrations, field visits etc., for needed perceptual changes among the soliga farmers. This will enable the soliga farmers to adopt nutririch crop cultivation practices which will inturn help in quality production of nutririch crops and enhancement of nutritional diet.

\section{Acknowledgements}

The authors are gratefully thanking DST-GOI for providing financial assistance to conduct this study.

\section{References}

Balasubramanian, S. and Perumal,G. 1989. Technology transfer of effectiveness in inland fish farming as perceived by extension personnel. Indian Journal of Extn.Edu., 25(3 \& 4): 8-15.

Christinck, A. 2002. "This seed is like ourselves": A case study from Rajasthan, India, on the social aspects of biodiversity and farmers' management of pearl millet seed. Margraf Publishers, Weikersheim.

Kerr, R.B., S. Snapp, M. Chirwa, L. Shumba and R. Msachi. 2007. Participatory research on legume diversification with Malawian smallholder farmers for improved human nutrition and soil fertility. Experimental Agriculture, 43(4): 437-453.

Kitch, L.W., O. Boukar, C. Endondo and L.L. Murdock. 1998. Farmer acceptability criteria in breeding cowpea. Experimental Agriculture, 34(4): 475-486.

Madhu Prasad, Ramakrishna Naika, Usha Ravindra and M.P. Gokulraj. 2010. Perception and adaptation of organic farming practices among mulberry cultivators. Agriculture Update. 5(3 \& 4): 306-308

Usha Ravindra, M.S.Uma, Madhu Prasad. V.L. and Chandrakala Hanagi. 2020. NutrifarmA tool to manage nutritional anaemia. $107^{\text {th }}$ Indian science congress -Women science congress held at UAS Bengaluru $5^{\text {th }}$ to $6^{\text {th }}$ January 2020.

How to cite this article:

Uma, M. S. and Usha Ravindra. 2020. Perception and Adoption of Nutririch Crops Cultivation Practices among Soliga Farmers. Int.J.Curr.Microbiol.App.Sci. 9(09): 2167-2170. doi: https://doi.org/10.20546/ijcmas.2020.909.271 